\title{
Experimental Study on Albino Rats to Evaluate the Anti-Anxiety Effect of Kushmanda Beej Choorna
}

\author{
Bharti $^{1}$, Sharma Subhash ${ }^{2}$, Toor $\operatorname{Raman}^{3}$, Sharma Manisha ${ }^{4}$ \\ ${ }^{1}$ M.D. Ayu, Reader, Deptt. of Kayachikitsa, G.N.A.M.C.,Gopalpur, Ludhiana(Pb.) \\ ${ }^{2}$ M.D. Ayu, Lecturer, Deptt. of panchkarma, G.N.A.M.C.,Gopalpur, Ludhiana(Pb.) \\ ${ }^{3}$ M.D. Ayu, Lecturer, Deptt. of Agad Tantra, G.N.A.M.C.,Gopalpur, Ludhiana(Pb.) \\ ${ }^{4}$ M.D. Ayu, Reader, Deptt. of Rog nidan, G.N.A.M.C., Gopalpur, Ludhiana(Pb.)
}

\begin{abstract}
Introduction: Anxiety Disorder is a Manasika Vikara mentioned in Ayurvedic literature which is a gift of today's stresseful lifestyle. In Ayurvedic classics, Medhya drugs like Kushmanda are indicated to improve functions of Manas and Buddhi.

Aims and Objectives: The study was planned on albino rats to evaluate the anti anxiety effect of Kushmanda beeja Choorna.

Materials and Methods: Kushmanda Beej Choorna was administered to 20 rats divided into 2 groups containing 10 rats in each group. From day 1 to day 5, two groups were administered through intra gastric tube using $2 \mathrm{ml}$ disposable syringe fitted with 18 gauze needle, with the estimated dose of distilled water and trial drug i.e. Beeja Choorna of Kushmanda respectively. On 6thday, one hour after the respective drug administration, effect was observed on the basis of animal model Elevated plus maze and few parameters were recorded.
\end{abstract}

Result: Dunnett's post hoc test and student unpaired ' $t$ ' test were applied to trial group in comparison with control group showed statistically highly significant result with $\mathrm{p}$ value $<0.001$ in the number of entries to the open arm, statistically significant result with p 0.002 on the latency of first entry to the closed arm and moderately statistically significant with $\mathrm{p} 0.012$ in time spent in open arms.

Conclusion: It was concluded that the trial formulation contains good anti anxiety properties so can be used in the management without any side effects.

Keywords: Anxiety, Ayurveda, Kushmanda

\section{Introduction}

In Ayurveda, Life is a conglomerate of body (Shareera), faculties (Indriya), mind (Satva), and soul (Atma). Shareera refers body including five senses and mind. Ayurveda defines a person healthy when along with physical well being i.e.Sharirika and Manasika Dosha Samata, Dhatu Samata and Agni Samata, there is psychological as well as spiritual well being of that person. Imbalance of those Sharirika as well as Manasika Doshas leads to Vikriti or illness. Chittodvega is one of the Manasika Vikara mentioned in Ayurvedic literature. The symptoms of this disease can be assumed mostly similar with the Anxiety disorder which is a gift of today's stressful lifestyle. In Modern Medicine, there is spectrum of drugs for its management but due to their excessive side effects and habit forming nature, there is a wide scope of research in other pathies to find out safe and effective remedy. In Ayurvedic classics, Medhya drugs are indicated to enhance the function of Buddhi, decreases the Raja and Tama Doshas and provides better functions to Manas and Buddhi. Kushmanda (Benincasa hispida) has been mentioned one among these Medhya drugs and is used for the treatment of Unmada and Apasmara. In this context, the Beej Choorna of 
Bharti $^{1}$, International Journal of Ayurvedic\& Herbal Medicine 8(4) Juyy.-August. 2018 (3289-3295)

Kushmanda is undertaken to experimentally evaluate the Anti - Anxiety activity on albino rats based on the animal model Elevated plus maze ${ }^{1}$.

\section{Materials And Methods}

The present study has been carried out with three headings:

1. Collection of the raw drug

2. Preparation of trial drug

3. Animal experimental study

The study was carried out in the Department of DravyaGuna, Post Graduation, Research wing-ARMARC (Quality Control Laboratory) and Anicut and Remal experimentation house (Approved by CPCSEA, Ministry of Environment and Forests, Government of India), ALNRMAMC, Koppa.

1. Collection of the raw drug: Kushmanda (Benincasa hispida (Thunb.) Cogn.) was identified and confirmed by botanists before collection of drug. Kushmanda is collected from near vicinity of Koppa. After cleaning the drugs with water, cut into pieces then seeds are collected and dried under sun shade and made into fine powder form.

2. Preparation of trial drug: Dried seeds of Kushmanda were taken in a Khalwa Yantra, made into a powder form by crushing and maceration and filtered with clean two layered cloth and collected the fine form of Choorna as required for the experiment.

\section{Experimental study: Source of Animals:}

The animals, albino rats were obtained from the Animal House, A.L.N. Rao Memorial Ayurvedic Medical College, Koppa. Total 20 rats were selected for the trial.

Inclusion criteria

Healthy and active albino rats (both sexes) Rats weighing $150 \mathrm{~g}-200 \mathrm{~g}$.

Exclusion criteria

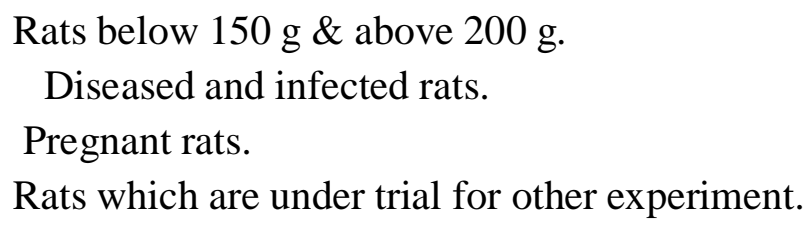

\section{Rat Maintenance}

All animals were maintained hygienically at the Animal House of A.L.N.R.A.M. College Koppa, under identical condition of place, light, temperature, humidity, food and other conditions.

Feeding Schedule

The quantity of food for rats weighing 150-200g was about 15-20g / day. Water was provided as required. Readymade rat feed prepared by Amrut feeds, Pranav Agro Industries 1td, Sangli was procured and used.

Elevated plus maze induced anxiety

For evaluation of anxiolytic properties of a drug the available animal experimental models are elevated plus maze, Y- maze, radial maze, mirror chambered apparatus, light and dark model. Elevated plus maze is the simplest apparatus to study anxiolytic response of almost all types of anti anxiety agents.

Exposure of the animals to novel maze alley evokes an approach avoidance conflict which is stronger in open arm as compared to enclosed arm. Rats have aversion for high and open space and prefer enclosed arm and therefore, spend greater amount of time in enclosed arm. When animal enter open arm, they freeze, become immobile, defecate and show fear like movements, as a true reflection of anxiety.

Materials used

- Elevated plus maze 
Bharti ${ }^{1}$, International Journal of Ayurvedic\& Herbal Medicine 8(4) Juyy.-August. 2018 (3289-3295)

- Trial drug: Beej Choorna of Kushmanda (Benincasa hispida (Thunb.) Cogn.

\section{Procedure:}

* Total 20 rats were divided into 2 groups, control and trial with 10 rats in each group.

* Total duration of the trial was 6 days.

* From day 1 to day 5 the rats were administered with the estimated dose of distilled water to control group and trial drug Beej Choorna of Kushmanda to trial group.

* Drug is administered through intra gastric tube using $2 \mathrm{ml}$ disposable syringe fitted with 18 gauze stainless steel needle provided with suitable smooth malleable plastic catheter in order to avoid injury to the esophagus of rats.

* Known quantity of drug was taken in the syringe and pushed directly into the stomach of the rats after inserting the catheter into esophagus carefully.

* On $6^{\text {th }}$ day, one hour after the respective drug administration individual rat was placed in the centre of the maze, head facing towards the open arms. Exposure to the elevated open arms induces anxiety in the rodents.

* The observation was made for 5 minutes and based on the parameters the observation was recorded.

Variables for effect:

Observations were carried out on the basis of following three parameters-

a) Number of entries to the open arm

b) time spent in the open arm

c) Latency of the first entry to the closed arm

Statistical analysis:

The readings were tabulated and statistically analyzed using one way Anova test with Dunnett's post hoc test. The comparison between both groups were statistically analyzed using unpaired ' $t$ ' test.

\section{Observations And Results}

Following parameters were recorded after administration of distilled water to control group and trial drug to trial group.

Table no I. parameters observed in the rats administered with the control distilled water.

\begin{tabular}{|l|c|c|c|}
\hline Parameters & NEOA* & TSOA** & LFECA*** $^{* *}$ \\
\hline Rat 1 & 1 & 42 & 5 \\
\hline Rat 2 & 1 & 82 & 7 \\
\hline Rat 3 & 1 & 24 & 4 \\
\hline Rat 4 & 1 & 30 & 3 \\
\hline Rat 5 & 0 & 40 & 8 \\
\hline Rat 6 & 1 & 18 & 4 \\
\hline Rat 7 & 1 & 24 & 4 \\
\hline Rat 8 & 1 & 25 & 6 \\
\hline Rat 9 & 0 & 36 & 5 \\
\hline Rat 10 & 1 & 18 & 3 \\
\hline
\end{tabular}

(*-no.of entries to the open arm, **- Total time spent in open arm, ***- latency of the first entry to the closed arm) 
Bharti $^{1}$, International Journal of Ayurvedic\& Herbal Medicine 8(4) Juyy.-August. 2018 (3289-3295)

Table no II. parameters observed in the rats administered with the trial drug, Kushmanda Beej Choorna

\begin{tabular}{|l|c|c|c|}
\hline Parameters & NEOA* & TSOA $^{* *}$ & LFECA*** $^{* *}$ \\
\hline Rat 1 & 2 & 74 & 7 \\
\hline Rat 2 & 1 & 76 & 9 \\
\hline Rat 3 & 3 & 85 & 7 \\
\hline Rat 4 & 1 & 63 & $\mathbf{8}$ \\
\hline Rat 5 & 2 & 72 & 9 \\
\hline Rat 6 & 3 & 68 & 8 \\
\hline Rat 7 & 1 & 80 & 9 \\
\hline Rat 8 & 2 & 58 & 8 \\
\hline Rat 9 & 1 & 72 & 6 \\
\hline Rat 10 & 2 & 80 & \\
\hline
\end{tabular}

(*-no.of entries to the open arm, $* *_{-}$Total time spent in open arm, $* *_{-}$latency of the first entry to the closed arm)

Statistical analysis of all groups through one way anova test:

Table no III result of the experimental study, expressed as Mean \pm SEM for both groups.

\begin{tabular}{|l|c|c|c|}
\hline Groups & $\begin{array}{c}\text { Number Of Entries } \\
\text { To Open Arm( In } \\
\text { Seconds) }\end{array}$ & $\begin{array}{c}\text { Time Spent In } \\
\text { Open Arm( In Seconds) }\end{array}$ & $\begin{array}{c}\text { Latency Of First } \\
\text { Entry To Closed Arm } \\
\text { (In Seconds.) }\end{array}$ \\
\hline Control & $1.0 \pm 1.49$ & $37.1 \pm 13.35$ & $5.1 \pm 0.74$ \\
\hline $\begin{array}{l}\text { Kushmanda } \\
\text { Beeja Choorna }\end{array}$ & $1.7 \pm 0.20$ & $76.8 \pm 2.67$ & $7.5 \pm 0.49$ \\
\hline
\end{tabular}

Following graphs were made according to the mean value recorded of individual parameter observed in the trial.

Graph no.I showing mean of NEOA of control and trial group




Bharti ${ }^{1}$, International Journal of Ayurvedic\& Herbal Medicine 8(4) Juyy.-August. 2018 (3289-3295)

Graph no.II showing mean of TSOA of control and trial group

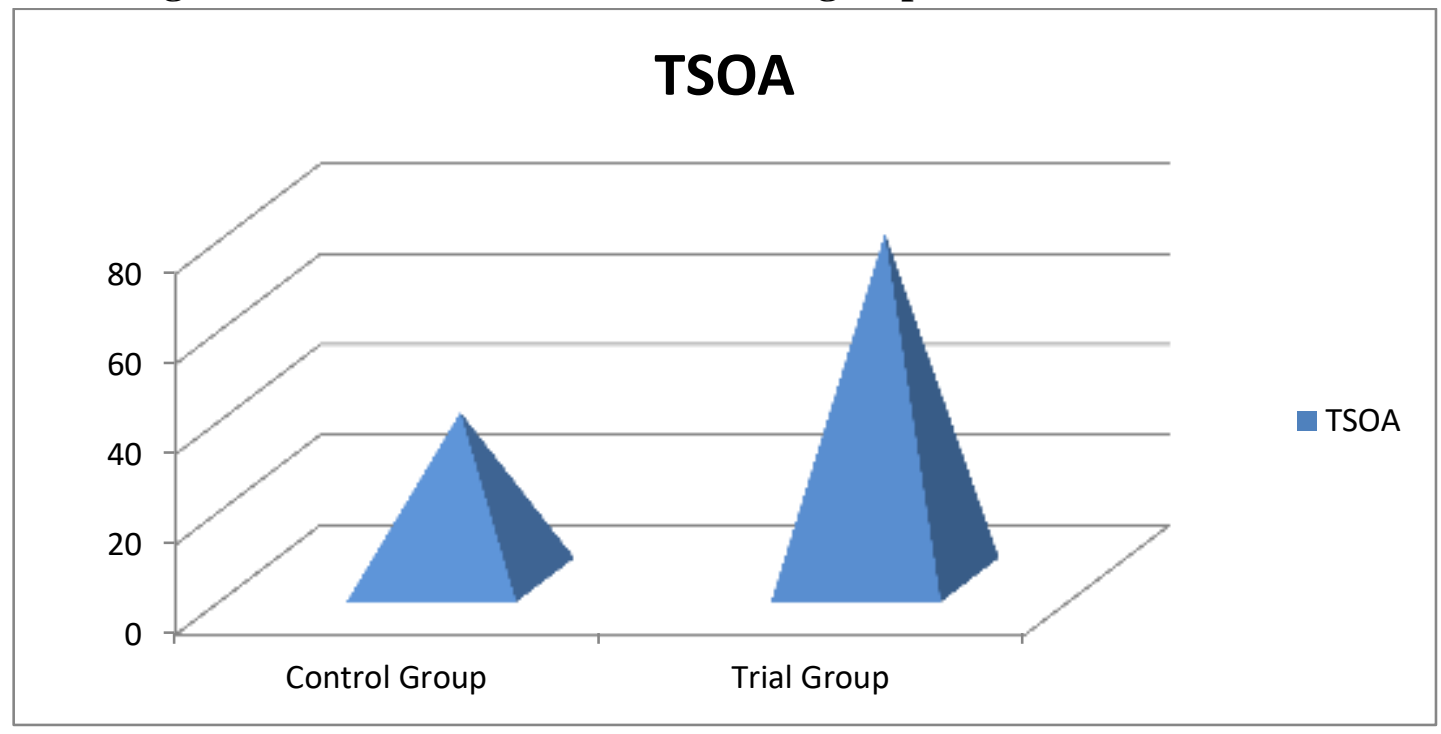

Graph no.III showing mean of LFECA of control and trial group

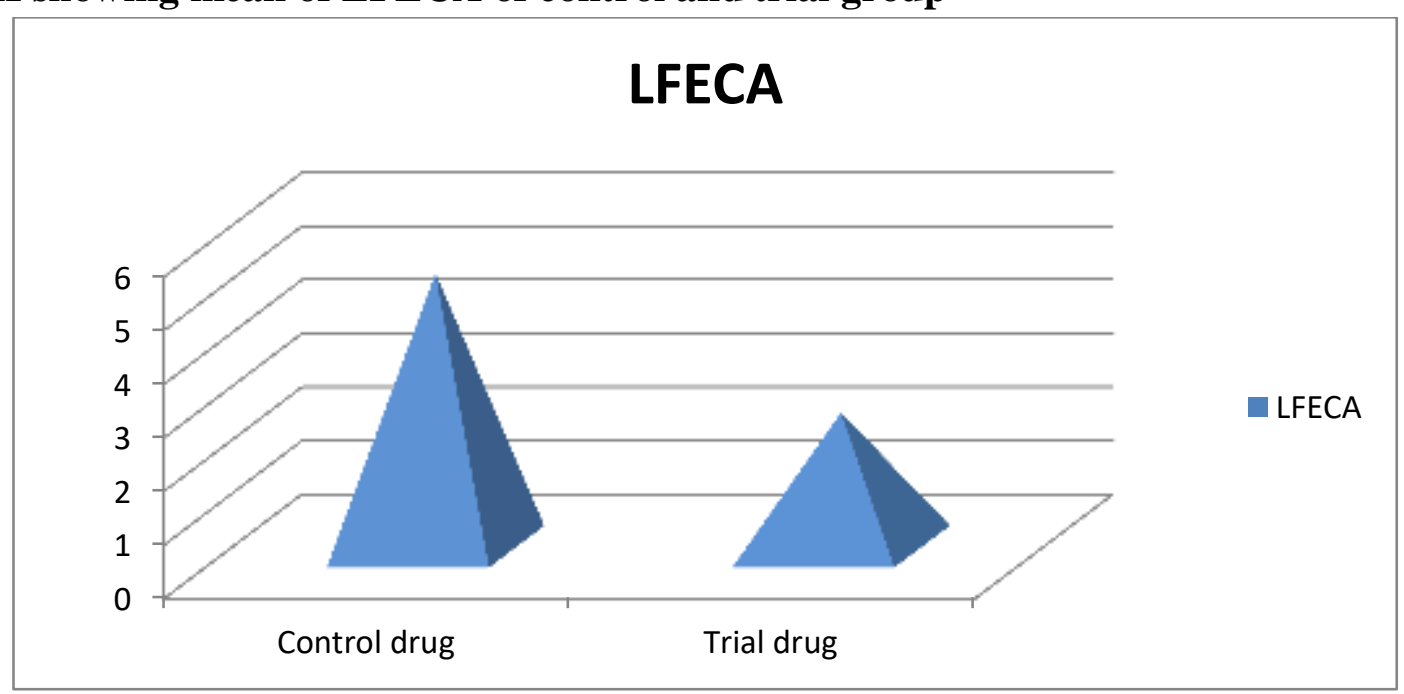

Significance between the control and the trial groups in the experiment were tested for significance using Dunnetts ' $t$ ' test, values of $p<0.05$ were considered as statistically significant.

Table no IV. showing the Dunnetts s test for comparison between the numbers of entries to the open arm.

\begin{tabular}{|c|c|c|}
\hline Parameters & Between control \& Trial drug \\
\hline & Difference in & \\
& mean & \\
\hline NEOA & 1.000 & Yes, statistically significant \\
\hline TSOA & 35.800 & Yes, statistically significant \\
\hline LEFCA & 2.700 & Yes statistically significant, \\
\hline
\end{tabular}


Bharti $^{1}$, International Journal of Ayurvedic\& Herbal Medicine 8(4) Juyy.-August. 2018 (3289-3295)

Table no V. showing results of unpaired $t$ test between the control group and trial drug (Kushmanda Beej Choorna) on all the parameters

\begin{tabular}{|c|c|c|c|c|}
\hline Parameter & Mean & T value & P value & Result \\
\hline NEOA & 1.0 & -4.16 & $<0.001$ & $\begin{array}{c}\text { Highly } \\
\text { Significant }\end{array}$ \\
\hline TSOA & 35.8 & -2.6 & $\mathbf{0 . 0 1 2}$ & $\begin{array}{c}\text { Merely } \\
\text { Significant }\end{array}$ Using Anova and Dun \\
\hline LEFCA & -2.7 & -3.70 & $\mathbf{0 . 0 0 2}$ & Significant \\
\hline
\end{tabular}

Applying student unpaired ' $\mathrm{t}$ ' test, the values of the parameter NEOA were compared between the Control group and Kushmanda Beej Choorna, the p value obtained was $<0.001$ suggestive of statistically highly significant result. Similarly, parameter TSOA was compared with p value 0.012 which is merely statistically significant. Comparison of the value of LEFCA parameter showed statistically significant result with $\mathrm{p}$ 0.002 .

\section{Discussion}

Experimental study

Rats think like humans, researchers have found that brains of the humans and the rats adapt in a similar way. The present study was undertaken to evaluate the anti- anxiety effect of the trial drug Kushmanda Beej Choorna on albino rats using animal experiment model, Elevated plus maze. Rats were administered with the decided dose of medicine for 5 days. On the $6^{\text {th }}$ day one hour after administration of the medicine, the rats were exposed to the Elevated plus maze individually.

Each rat was placed at the centre of the elevated plus maze facing the open arm. The rats were observed for 5 minutes (parameters were recorded in seconds) and the observations were recorded. Rodents have a natural aversion for high and open space and therefore they prefer closed arms, which have burrow like ambience. When exposed to novel maze allay, the animals experience an approach-avoidance conflict, which was stronger in the open arms as compared to the closed arms. The decreased aversion to the open arms was the result of an anxiolytic effect which was expressed by an increased number of entries to the open arm, time spent in the open arm and latency of first entry to the enclosed arm. Pre-treatment with the trial drug significantly increased the number of entries to open arm, time spent in open arm and the latency of first entry to the closed arm. This indicates the anxiolytic effect of the trial drugs when compared with the control group.

\section{Probable mode of action}

Chittodvega (Anxiety Disorder) is a Vata predominant disease associated with Kapha, where the Samjnavaha Srotas is blocked. Kushmanda has Madhura Rasa; it does the Vatahara action. Simultaneously, due to its Kshara Guna and its Ksharana property, removes the Margavarodha created by Kapha.

Phytochemical analysis suggests the presence of compounds like steroids, flavonoids ${ }^{3}$, terpenoids, tannins ${ }^{4}$, saponin ${ }^{5}$, alkaloids and in fair amount in the trial drug. The derivatives of these compounds produce their effect by modulation of GABAergics on the $\mathrm{CNS}^{6}$ thus acting as anxiolytic.

So based on the experimental study, both the drugs show good result in evaluating anxiety on the albino rats. 
Bharti $^{1}$, International Journal of Ayurvedic\& Herbal Medicine 8(4) Juyy.-August. 2018 (3289-3295)

\section{Acknowledgement}

I express my deep sense of gratitude with profound respect to Dr. H.R.Pradeep M.D.(Ayu), Professor, Department of Post graduate Studies in Dravya guna, and Dr. Shilpa K.N M.D.(Ayu)for his valuable guidance. I pay my immense thanks to Dr. Karthik, H.V., Incharge of animal house for their help in the experimental studies.

\section{References}

1. Walf Alicia A, zfrye Cheryl A. The use of the elevated plus maze as an assay of anxiety-related behaviour in rodents. Nat. Protoc. 2007; 2(2):322-328. (https://www.ncbi.nlm.nih.gov/pmc/articles/PMC3623971/) CITED ON 23 ${ }^{\mathrm{RD}}$ JUNE 2018

2. Chiba Andrea. Why we use rodents to research the brain. The San Diego Union-Tribune, copyright (C) 2018

3. Al-Snafi Ali Esmail. The Pharmacological Importance of Benincasa hispida. A review. International Journal of Pharma Sciences and Research, Vol.4 No 12 Dec.2013 P.165-170

4. Une Hemant Devidas, Doshi Gaurav. Chromatographic studies on Benincasa hispida seed extract scrutinized by HPLC and HPTLC. Pharmacognosy Journal, April 2014, 6(3):42-48.

5. 5.Nadhiya K, Haripriya D, Vijayalakshmi K. Pharmacognostic and preliminary phytochemical analysis of Benincasa hispida Fruit.Asian Journal of Pharmaceutical and Clinical Research, Vol.7, issue 1, 2014, P.-98-101

6. Ambikar D.B, Mohanta G.P. Effect of Dried Fruit extract of Benincasa hispida on Brain behaviour in Laboratory Animals. Journal of Cell and Tissue Research. 2013, Vol.13 Issue 1, p 3519-3524 